patients without evidence of immunosuppression and in patients with suspected atypical pneumonia. Eur J Clin Microbiol Infect Dis 1993;12:105-109.

2. Pifer LL, Hughes WT, Stagno S, Woods D. Pneumocystis carinii infection: evidence for high prevalence in normal and immunosuppressed children. Pediatrics 1978;61:35-41.

3. Gerrard MP, Eden OB, Jameson B, Craft AW. Serological study of Pneumocystis carinii infection in the absence of immunosuppression. Arch Dis Child 1987;62:177-179.

4. Smulian AG, Sullivan DW, Linke MJ, Halsey NA, Quinn TC, MacPhail AP, et al. Geographic variation in the humoral response to Pneumocystis carinii. J Infect Dis 1993;167:1243-1247.

5. Shepherd V, Jameson B, Knowles GK. Pneumocystis carinii pneumonitis: a serological study. J Clin Pathol 1979;32:773-777.

6. Kovacs JA, Halpern JL, Swan JC, Moss J, Parillo JE, Masur H. Identification of antigens and antibodies specific for Pneumocystis carinii. J Immunol 1988;140:2023-2031.

7. Sepkowitz K, Schluger N, Godwin T, Armstrong D, Cerami A, Bucala R DNA amplification in experimental pneumocystosis: characterization of serum Pneumocystis carinii DNA and potential P. carinii carrier states. $J$ Infect Dis 1993;168:421-426.

8. Vargas SL, Hughes WT, Wakefield AE, Oz HS. Limited persistence in and subsequent elimination of Pneumocystis carinii from the lungs after P. carinii pneumonia. J Infect Dis 1995;172:506-510.

9. Stiller RA, Paradis IL, Dauber JH. Subclinical pneumonitis due to Pneumocystis carinii in a young adult with elevated antibody titers to EpsteinBarr virus. J Infect Dis 1992;166:926-930.

10. Elvin K. Laboratory diagnosis and occurrence of Pneumocystis carinii. Scand J Infect Dis 1994;94(suppl):1-34.

11. Millard PR, Heryet AR. Observations favouring Pneumocystis carinii pneumonia as a primary infection: a monoclonal antibody study on paraffin sections. J Pathol 1988;154:365-370.

12. Perera DR, Western KA, Johnson HD, Johnson WW, Schultz MG, Akers PV. Pneumocystis carinii pneumonia in a hospital for children. Epidemiologic aspects. JAMA 1970;214:1074-1078

13. Singer C, Armstrong D, Rosen PP, Schottenfeld D. Pneumocystis carinii pneumonia: a cluster of eleven cases. Ann Intern Med 1975;82:772-777.

14. Hennequin C, Page B, Roux P, Legendre C, Kreis H. Outbreak of Pneumocystis carinii pneumonia in a renal transplant unit. Eur J Clin Microbiol Infect Dis 1995;14:122-126.

15. Branten AJ, Beckers PJ, Tiggeler RG, Hoitsma AJ. Pneumocystis carinii pneumonia in renal transplant recipients. Nephrol Dial Transplant 1995;10:1194-1197.

16. Chave JP, David S, Wauters JP, Van Melle G, Francioli P. Transmission of Pneumocystis carinii from AIDS patients to other Immunosuppressed patients: a cluster of Pneumocystis carinii pneumonia in renal transplant recipients. AIDS 1991;5:927-932.

17. Cheung YF, Chan CF, Lee CW, Lau YL. An outbreak of Pneumocystis carinii pneumonia in children with malignancy. J Paediatr Child Health
1994;30:173-175.

18. Varthalitis I, Aoun M, Daneau D, Meunier F. Pneumocystis carinii pneumonia in patients with cancer. An increasing incidence. Cancer 1993;71:481-485.

19. Mounib B, Cabane J, Blum L, Picard O, Wattiaux MJ, Imbert JC. Risk of nosocomial Pneumocystis carinii pneumonia in immunosuppressed patients non-infected by human immunodeficiency viruses. Rev Med Interne 1994:15:95-100.

20. Harmsen AG, Chen W, Gigliotti F. Active immunity to Pneumocystis carinii reinfection in T-cell-depleted mice. Infect Immun 1995;63:23912395.

21. Lundgren B, Kovacs JA, Mathiesen L, Nielsen JO, Lundgren JD. IgM response to a human Pneumocystis carinii surface antigen in HIV- infected patients with pulmonary symptoms. Scand J Infect Dis 1993;25:515520

22. Leigh TR, Millett MJ, Jameson B, Collins JV. Serum titres of Pneumocystis carinii antibody in health care workers caring for patients with AIDS. Thorax 1993;48:619-621.

23. Lidman C, Olsson M, Bjorkman A, Elvin K. No evidence of nosocomial Pneumocystis carinii infection via health care personnel. Scand J Infect Dis 1997;29:63-64.

24. Lundgren B, Elvin K, Rothman LP, Ljungstrom I, Lidman C, Lundgren JD. Transmission of Pneumocystis carinii from patients to hospital staff. Thorax 1997;52:422-424.

25. Margutti P, Visconti E, Mencarini P, Zolfo M, Marinaci S, Tamburrini E, et al. Typing with ITS regions of $P$ carinii from AIDS patients with recurrent pneumonia. J Eukaryot Microbiol 1997;44:50S.

26. Tsolaki AG, Miller RF, Underwood AP, Banerji S, Wakefield AE. Genetic diversity at the internal transcribed spacer regions of the rRNA operon among isolates of Pneumocystis carinii from AIDS patients with recurrent pneumonia. J Infect Dis 1996;174:141-156.

27. Keely SP, Stringer JR. Sequences of Pneumocystis carinii f. sp. hominis strains associated with recurrent pneumonia vary at multiple loci. J Clin Microbiol 1997;35:2745-2747.

28. Beard CB, Navin TR. Molecular epidemiology of Pneumocystis carinii pneumonia. Emerging Infectious Diseases 1996;2:147-150.

29. Centers for Disease Control and Prevention. Report of the NIH panel to define principles of therapy of HIV infection and guidelines for the use of antiretroviral agents for HIV-infected adults and adolescents. MMWR 1998;47:1-91.

30. Bloch K, Pletcher M, Zwerling L, Gerberding J, Ostroff S, Reingold S. A Population-Based Study of the Emergence of M. kansasii. Program and Abstracts of the 35th Annual Meeting of the Infectious Diseases Society of America; San Francisco, CA; October 1998.

31. Sanchez V, Vazquez JA, Barth-Jones D, Dembry L, Sobel JD, Zervos MJ. Nosocomial acquisition of Candida parapsilosis: an epidemiologic study. Am J Med 1993;94:577-582.

\title{
Mad Cow Disease From Drinking Water?
}

\section{Gina Pugliese, RN, MS Martin S. Favero, PhD}

Bovine spongiform encephalopathy (BSE) is believed to be transmitted by the ingestion of proteinaceous agents called prions, which accumulate in the brain and spinal cord of infected bovines. Concern has been expressed about the risks of transmission of BSE to humans through BSE prions discharged to the aquatic environment from rendering plants, abattoirs, and landfills. The disease-related form of the prion protein is relatively resistant to degradation, and infectivity decays rather slowly in the environment. Levels of disinfection used for drinking-water treatment would have little effect.
Gale and co-investigators recently modeled the risks from a rendering plant disposing of cull cattle carcasses in the catchment of a chalk aquifer, which is used for a drinking-water abstraction. The riskassessment approach focused on identifying the hydrogeological and physical barriers that would contribute to preventing BSE infectivity gaining entry to the aquifer. These barriers included inactivation of BSE agent by the rendering process, removal from the effluent by treatment at the plant, filtration and adsorption in the clay and chalk, and dilution in the ground water. The importance in environmental risk assessment of the cow-to-man species barrier is considered. Two key conclusions about the environmental behavior of the BSE agent are that prion proteins are "sticky" and bind to particulates and that the millions of BSE prion molecules comprising a human oral $\mathrm{ID}_{50}$ are subject to some degree of dispersion and hence dilution in the environment. Assuming the rendering plant processes 2,000 cull cattle carcasses per week, the risks to drinking-water consumers were estimated to be remote. Indeed, even using worst-case assumptions, an individual would have to consume $21 \mathrm{dL}$ of tap water for 45 million years to have a $50 \%$ chance of infection through drinking water drawn from the aquifer.

FROM: Gale P, Young C, Stanfield G, Oakes D. Development of a risk assessment for BSE in the aquatic environment. J Appl Microbiol 1998;84:467-477. 